\title{
Short-term Prophylaxis for Delivery in Pregnant Women with Hereditary Angioedema with Normal C1-Inhibitor
}

\section{Profilaxia de curto prazo para o parto em grávidas com angioedema hereditário com inibidor de C1 normal}

Caroline Guth de Freitas Batista de Moraes ${ }^{1}$ Liya Regina Mikami $^{2}{ }^{\circledR} \quad$ Lilian Pereira Ferrari2 João Bosco Pesquero ${ }^{3(1)}$ Herberto José Chong-Neto ${ }^{1 \odot}$ Nelson Augusto Rosario Filho ${ }^{10}$

1 Universidade Federal do Paraná, Curitiba, PR, Brazil

${ }^{2}$ Centro Universitário Autônomo do Brasil, Curitiba, PR, Brazil

3 Universidade Federal de São Paulo, São Paulo, SP, Brazil
Address for correspondence Caroline Guth de Freitas Batista de Moraes, MSc, Rua Padre Camargo, 453, Curitiba, PR, 80030-110, Brazil (e-mail: carolguth@gmail.com).

Rev Bras Ginecol Obstet 2020;42(12):845-848.

received

February 18, 2020

accepted

September 17, 2020
Objective To verify the efficacy of short-term prophylaxis for vaginal or cesarean section childbirth with plasma-derived C1-inhibitor concentrate in pregnant women. They should have hereditary angioedema (HAE) and normal plasma C1-inhibitor. Methods Case report of pregnant women diagnosed with HAE with normal C1inhibitor who had been treated with intravenous C1-inhibitor concentrate for prophylaxis of angioedema attacks when hospitalized for delivery. The exon 9 of the Factor 12 (F12) genotyping gene was performed by automatic sequencing in all patients.

Results Three cases of pregnant women with HAE with normal serum level of C1inhibitor are reported. The genetic test detected the presence of a pathogenic mutation in the $F 12$ gene. Deliveries occurred uneventfully and patients had no HAE symptoms in the following 72 hours.

Conclusion C1-inhibitor concentrate could be useful to prevent angioedema attacks during and after delivery.

Objetivo Verificar a eficácia da profilaxia de curto prazo para o parto vaginal ou cesáreo com inibidor de $\mathrm{C} 1$ derivado de plasma concentrado em mulheres grávidas. Eles devem ter angioedema hereditário e inibidor normal de C1 no plasma.

Métodos Relato de caso de gestantes diagnosticadas com angioedema hereditário com inibidor de $\mathrm{C} 1$ normal que foram tratadas com inibidor intravenoso de concentrado de C1 para profilaxia de ataques de angioedema quando hospitalizadas para o parto. O exon 9 do gene de genotipagem do fator 12 (F12) foi realizado por sequenciamento automático em todos os pacientes.

- gravidez

- profilaxia

DOI https://doi.org/

10.1055/s-0040-1718955. ISSN 0100-7203.
Copyright $\odot 2020$ by Thieme Revinter

Publicações Ltda, Rio de Janeiro, Brazil
License terms

(c) (1) 
Resultados Três casos de gestantes com angioedema hereditário com nível sérico normal de inibidor de C1 são relatados. O teste genético detectou a presença de uma mutação patogênica no gene F12. Os partos ocorreram sem intercorrências e as pacientes não apresentaram sintomas hereditários de angioedema nas 72 horas seguintes.

Conclusão $\mathrm{O}$ concentrado de inibidor de $\mathrm{C} 1$ pode ser útil para prevenir ataques de angioedema durante e após o parto.

\section{Introduction}

Hereditary angioedema (HAE) is a rare disease, and its prevalence is estimated to be $\sim 1: 50,000$ inhabitants. It is a genetic disorder of autosomal dominant inheritance. It is defined by the quantitative and/or functional deficiency of C1 esterase inhibitor (C1-INH), or with normal C1-INH and alteration in genes encoding Hageman factor XII (FXII) of the blood coagulation cascade. ${ }^{1,2}$ It leads to edema attacks in the skin and submucosa, in the regions of the face, extremities, genitalia, oropharynx, larynx, tongue, airway and gastrointestinal tract with risk of death from airway obstruction. ${ }^{1,2}$

The association between the disease and the estrogen hormone is the main feature of HAE with normal C1-INH. Elevated levels of this hormone in pregnancy, or the use of oral contraceptives, stress and menstrual cycles are triggers of this type of HAE. ${ }^{1,3,4}$ Thus, symptoms may become more frequent and severe during pregnancy, delivery, postpartum and lactation in women with HAE. ${ }^{5,6}$

Pregnant women with HAE with low level or functional deficiency of C1-INH should be treated with plasma-derived C1 inhibitor concentrate until 6 hours before delivery and could be repeated as needed, as well as 72 hours after the delivery. ${ }^{1}$ The hospital where the delivery will take place should have short-term preventive medications such as plasma-derived $\mathrm{C} 1$ inhibitor concentrate and trained personnel for the care of patients with HAE. ${ }^{4-6}$

There is no data regarding plasma-derived $\mathrm{C} 1$ inhibitor concentrate short-term prophylaxis for HAE with normal C1INH. The objective of the present study was to verify the efficacy of short-term prophylaxis of attacks in vaginal or cesarean delivery with plasma-derived C1-inhibitor concentrate in three pregnant women with HAE and normal C1inhibitor confirmed by molecular mutation analysis of the F12 gene.

\section{Description of Cases}

We report three pregnant patients diagnosed with HAE and F12 gene mutation attending the Immunology Division of the Hospital de Clínicas of the Universidade Federal do Paraná in 2018. All three had normal serum levels of C1-INH and C4. Of these, 2 are first cousins (patients 1 and 2) and they all agreed to participate in the present study and signed the informed consent form. Exon 9 genotyping, as well as its flanking regions and splicing sites of the F12 gene, was performed by automated sequencing on an $\mathrm{ABI} 3500$ Genetic Analyzer sequencer (Applied Biosystems, Foster City, CA, USA).

\section{Patient 1}

Female, 31 years old, primiparous. She reports clinical signs of HAE for 9 years, usually marked lip and facial edema, requiring medical attention and treated with corticosteroids, adrenaline and antihistamines. She did not identify any triggering factors.

Menarche at 15 years old, and she started contraception at 19 years old. At 29 years old, she became pregnant and reported left lower eyelid edema, lasting 5 hours and without treatment, sagging spontaneously.

Mutation search for the factor XII F12 gene revealed the presence of the c.983C $>$ A mutation in pathogenic heterozygosis (p.Thr328Lys) and confirmed the hypothesis of HAE without C1-INH deficiency.

Plasma-derived C1 esterase inhibitor, 1,000 IU, was administered intravenously 6 hours before cesarean section for short-term prophylaxis at delivery and postpartum. There were no complications during the surgical procedure and within 72 hours, subsequently.

\section{Patient 2}

Female, 44 years old, menarche at 12 years old. She reported lip and facial edema in the first pregnancy, 22 years ago. After this period, she had monthly angioedema attacks in the extremities and abdominal pain. During the attacks, she was treated with adrenaline and corticosteroids, unsuccessfully. The contraceptive was the only medication for continuous use. At 38 years old, she had severe upper airway edema requiring orotracheal intubation and hospitalization for 4 days, and no triggers could be pointed out.

A search for mutation of factor XII F12 gene confirmed the presence of the mutation c.983C $>\mathrm{A}$ in pathogenic heterozygosis (p.Thr328Lys) and confirmed HAE with no C1-INH deficiency.

When she was 43 years old, at the end of the pregnancy, she reported edema in the hands and legs. Fetal echocardiography showed subcutaneous edema and increased echogenicity in intestinal loops with increased peristalsis. The patient was hospitalized for dyspnea and successfully treated with fresh plasma.

The cesarean section at the $39^{\text {th }}$ gestational week was performed for fetal malformation. The patient received $1,000 \mathrm{IU}$ of intravenous $\mathrm{C} 1$-INH inhibitor 1 hour before the 


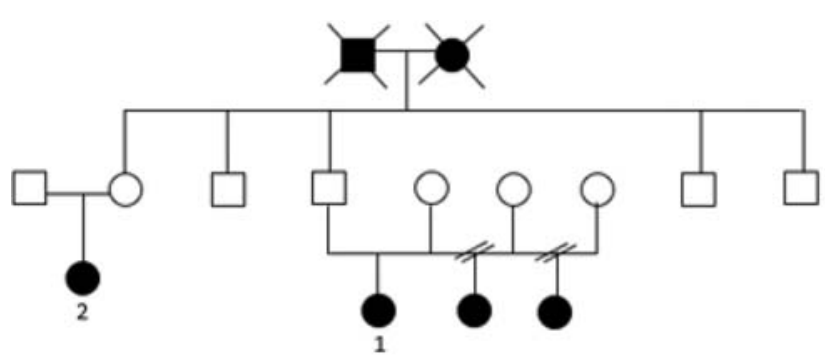

Key:

$\square$ HAE with p.Thr328Lys

$\square$ Without HAE

Fig. 1 Family Heredogram (Patients 1 and 2).

cesarean section without complications during the procedure and 72 hours postpartum (-Fig. 1).

\section{Patient 03}

Female, 20 years old, primiparous, single HAE case in the family. Menarche at 11 years old. Abdominal pain began in childhood and, from the age of 15 years old, monthly edema attacks of lips, tongue, face, eyelids, hands, and feet lasting from 3 to 4 days without improvement and no response to adrenaline and corticosteroids. She was treated with fresh plasma with improved outcomes.

Mutation search for the factor XII F12 gene confirmed the presence of the mutation c.983C $>\mathrm{A}$ in pathogenic heterozygosis (p.Thr328Lys) and confirmed HAE without C1-INH deficiency.

She got pregnant at 19 years old and reported 2 episodes of foot edema and mild lip edema, without medical complications, improving in 12 hours. The patient received intravenous $\mathrm{C} 1$ inhibitor, 1,000 IU, 1 hour before vaginal delivery for short-term prophylaxis. During the labor and postpartum, the patient was in good general condition, and 2 days after the delivery she had edema attacks in her left hand (-Table 1).

\section{Discussion}

Hereditary angioedema with normal C1-INH was first described in the year $2000 .^{6}$ As noted, it is rare, mainly affects women, and is characterized by normal C1-INH levels and activities $^{7}$ and by mutations in the $F 12$ gene. ${ }^{8}$

A predominance in females is associated with the estrogen hormone, a hallmark of HAE with normal C1-INH. ${ }^{5,7}$ Estrogen has a regulatory role in the synthesis of FXII protein, as well as of several genes and proteins of the coagulation cascade and of the kallikrein-kinin system, increasing synthesis of bradykinin, kallikrein, vascular permeability and consequently causing edema. ${ }^{9}$ This association is important in worsening the attacks in women, ranging from childhood, puberty, menses, pregnancy and menopause. ${ }^{1}$

Short-term prophylaxis with C1-INH concentrate administration up to 6 hours before the procedure or having a dose of C1-INH concentrate available in the delivery room is recommended to prevent a possible bout of edema during childbirth in women with HAE with C1-INH deficiency, but not for HAE with normal C1-INH. ${ }^{3,7}$

The present report of three pregnant patients demonstrated the efficacy and safety of plasma-derived C1-INH as short-term prophylaxis for HAE with normal C1-INH. There was no severe edema during vaginal delivery and/or cesarean section after the intravenous use of C1-INH concentrate. Surgical stress and mechanical abdominal trauma for cesarean delivery or genital mechanical trauma for normal delivery may be triggering factors for HAE. ${ }^{10}$

In the postpartum period, special attention should be given to edema triggers. ${ }^{10}$ Postpartum seizures usually occur within 72 hours of delivery and can have serious consequences. ${ }^{1}$ Patients show different symptoms in the attacks (left lower eyelid edema, left hand edema, vaginal bleeding and hypotension) starting 48 hours after delivery, demonstrating the need for protective medication immediately after delivery. ${ }^{7} \mathrm{C} 1$-INH concentrate shortens the duration of attacks by about one third and also reduces the time for the onset of symptom relief. ${ }^{11}$

The reported cases bring to light the discussion of preventive therapy of a complex and serious situation, which is the occurrence of HAE attacks during pregnancy and childbirth. Although used in a minority of cases, these should be adequately selected and their diagnosis confirmed by molecular tools. C1-INH concentrate can produce satisfactory results in symptomatic relief and improvement of the quality of life of the patients, especially postpartum. In Brazil, C1INH concentrate is approved; however, it is not yet included in the list of high-cost drugs provided by the government and only by demand of judicial request to the public health system. ${ }^{1}$

\section{Conclusion}

In conclusion, short-term prophylaxis using C1-INH concentrate in vaginal or cesarean delivery could be useful in pregnant patients with HAE and normal C1-INH. Larger

Table 1 Laboratory workout

\begin{tabular}{lllll}
\hline & Case 1 & Case 2 & Case 3 & Reference values \\
\hline C4 Complement Fraction (mg/dL) & 22 & 27 & 19 & $10-40$ \\
Quantitative C1 Inhibitor (mg/dL) & 26 & 20 & 28.8 & $21-39$ \\
Functional C1 Inhibitor (\%) & 81 & 85 & 71 & $70-130$ \\
\hline
\end{tabular}


studies may verify how C1-INH prevents attacks of HAE in pregnant women with HAE and normal C1-INH.

\section{Conflict of Interests}

The authors have no conflict of interests to declare.

\section{Acknowledgments}

The present work was supported by grants from CAPES (Coordenação de Aperfeiçoamento de Pessoal de Nível Superior), Brazil.

\section{References}

1 Giavina-Bianchi P, Arruda LK, Aun MV, et al. Diretrizes brasileiras para o diagnóstico e tratamento do angioedema hereditário2017. Arq Asma Alerg Imunol. 2017;1(01):23-48. Doi: 10.5935/2526-5393.20170005

2 Valle SOR, França AT, Campos RA, Grumach AS. Angioedema hereditário. Rev Bras Alerg Imunopatol. 2010;33(03):80-87

3 Sim DW, Park KH, Lee JH, Park JW. A case of type 2 hereditary angioedema with SERPING1 mutation. Allergy Asthma Immunol Res. 2017;9(01):96-98. Doi: 10.4168/aair.2017.9.1.96

4 Caballero T, Farkas H, Bouillet L, Bowen T, Gompel A, Fagerberg C, et al; C-1-INH Deficiency Working Group. International consensus and practical guidelines on the gynecologic and obstetric management of female patients with hereditary angioedema caused by C1 inhibitor deficiency. J Allergy Clin Immunol. 2012;129(02): 308-320. Doi: 10.1016/j.jaci.2011.11.025

5 Zuraw BL, Bork K, Binkley KE, Banerji A, Christiansen SC, Castaldo $A$, et al. Hereditary angioedema with normal C1 inhibitor function: consensus of an international expert panel. Allergy Asthma Proc. 2012;33(Suppl 1):S145-S156. Doi: 10.2500/ aap.2012.33.3627

6 Bouillet L, Gompel A. Hereditary angioedema in women: specific challenges. Immunol Allergy Clin North Am. 2013;33(04): 505-511. Doi: 10.1016/j.iac.2013.07.006

7 Riedl MA. Hereditary angioedema with normal C1-INH (HAE type III). J Allergy Clin Immunol Pract. 2013;1(05):427-432. Doi: 10.1016/j.jaip.2013.06.004

8 Bork K, Wulff K, Meinke P, Wagner N, Hardt J, Witzke G. A novel mutation in the coagulation factor 12 gene in subjects with hereditary angioedema and normal C1-inhibitor. Clin Immunol. 2011;141(01):31-35. Doi: 10.1016/j.clim.2011.07.002

9 Bork K. Hereditary angioedema with normal C1 inhibitor. Immunol Allergy Clin North Am. 2013;33(04):457-470. Doi: 10.1016/j. iac.2013.07.002

10 Maurer M, Magerl M, Ansotegui I, Aygören-Pürsün E, Betschel S, Bork $\mathrm{K}$, et al. The international WAO/EAACI guideline for the management of hereditary angioedema-The 2017 revision and update. Allergy. 2018;73(08):1575-1596. Doi: 10.1111/all.13384

11 Gompels MM, Lock RJ, Abinun M, Bethune CA, Davies G, Grattan C, et al. C1 inhibitor deficiency: consensus document. Clin Exp Immunol. 2005;139(03):379-394. Doi: 10.1111/j.13652249.2005.02726.x 